Section Editor

Mitchell S.V. Elkind,

MD, MS

\section{Teaching NeuroImages: \\ Harlequin syndrome caused by lesion of sympathetic regulatory neurons}

Saeed Bohlega, MD,

FAAN

Bent Stigsby, MD, PhD

Fahd Al Mohaileb, MD

Address correspondence and reprint requests to Dr. Saeed Bohlega, MBC 76, Department of Neurosciences, King Faisal Specialist Hospital and Research Centre, PO Box 3354, Riyadh 11211, Saudi Arabia boholega@kfshrc.edu.sa
A 48-year-old woman presented with a 6-year history of recurrent episodes of exertional asymmetric flushing of the face and head. After exercise, she observed a distinct line of demarcation between the left half of her face, which was red, and the right half, which retained its normal color (figure, A). Decreased right facial temperature and sweating were also noted. These episodes resolved after 1 hour of rest. She had no ptosis or myosis. She had mild trauma to the right neck 2 years prior to this complaint.

MRI of head, neck, and cervicobrachial plexus were normal. CT angiogram of the right internal carotid artery showed a small segmented stenosis (figure, $\mathrm{B}$ and $\mathrm{C}$ ). Loss of flushing on one side of the face indicates an ipsilateral lesion of sympathetic neurons innervating the face. The absence of Horner syndrome indicates intact oculosympathetic fibers. ${ }^{1,2}$ This rare and clinically striking syndrome may result from occult carotid dissection. ${ }^{3}$

\section{REFERENCES}

1. Drummond PD, Finch PM. Reflex control of facial flushing during body heating in man. Brain 1989;112:13511358.

2. Wasner G, Maag R, Ludwig J, et al. Harlequin syndrome: one face of many etiologies: case study. Nat Clin Pract Neurol 2005;1:54-59.

3. Sarikaya H, Georgiadis D, Baumgartner R. Harlequin syndrome in spontaneous dissection of the cervical carotid artery. Neurology 2008;71:1459.
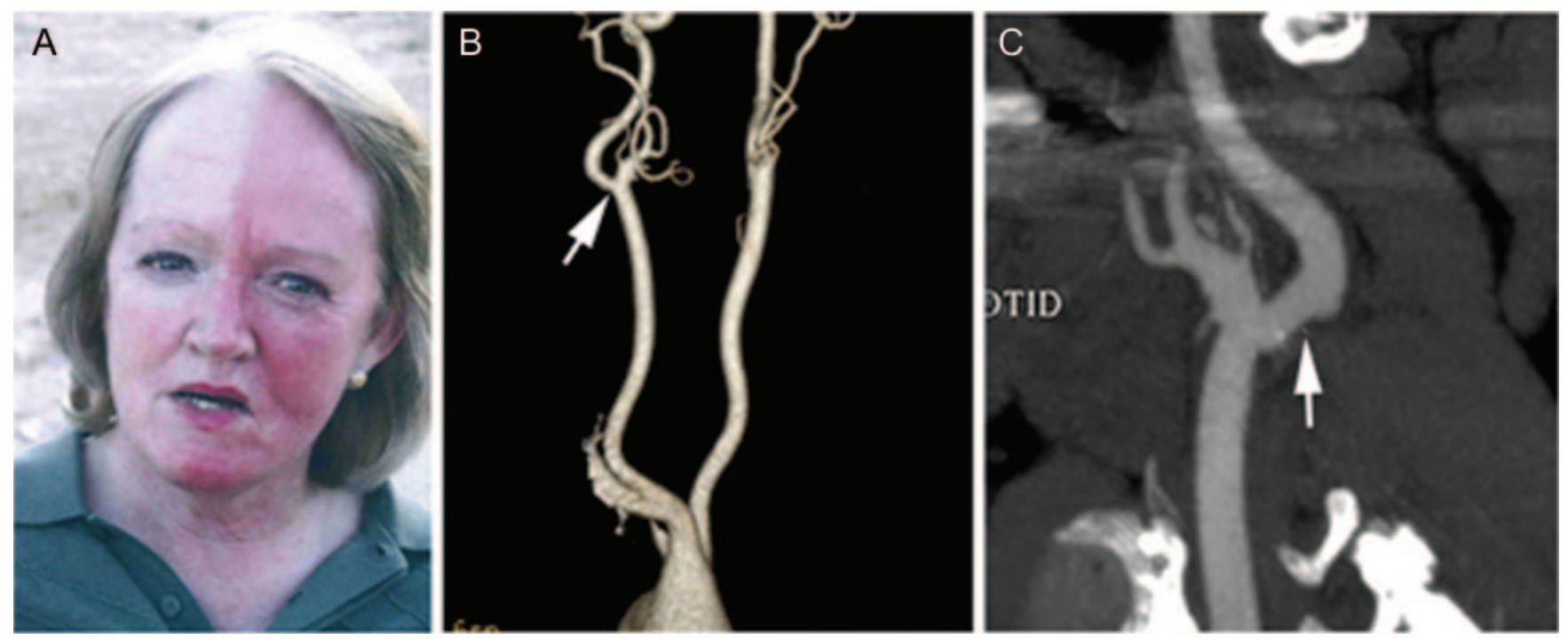

(A) The patient after exertion showing loss of right-sided flushing and sweating of the face and head. The left side showed normal flushing. (B) Threedimensional and (C) 2-dimensional CT angiogram of the carotid artery showing stenosis at the origin of the right internal carotid artery.

From the Departments of Neurosciences and Radiology, King Faisal Specialist Hospital and Research Centre, Riyadh, Saudi Arabia. Disclosure: Dr. Bohlega reports no disclosures. Dr. Stigsby serves on the editorial board of Clinical Neurology and Neurosurgery. Dr. Al-Mohaileb reports no disclosures. 


\section{Neurology}

\section{Teaching NeuroImages: Harlequin syndrome caused by lesion of sympathetic regulatory neurons}

Saeed Bohlega, Bent Stigsby and Fahd Al Mohaileb

Neurology 2010;74;e106

DOI 10.1212/WNL.0b013e3181e3963c

This information is current as of June 14, 2010

\section{Updated Information \&} Services

References

Citations

Permissions \& Licensing

Reprints including high resolution figures, can be found at: http://n.neurology.org/content/74/24/e106.full

This article cites 3 articles, 1 of which you can access for free at: http://n.neurology.org/content/74/24/e106.full\#ref-list-1

This article has been cited by 1 HighWire-hosted articles: http://n.neurology.org/content/74/24/e106.full\#\#otherarticles

Information about reproducing this article in parts (figures,tables) or in its entirety can be found online at:

http://www.neurology.org/about/about_the_journal\#permissions

Information about ordering reprints can be found online:

http://n.neurology.org/subscribers/advertise

Neurology ${ }^{\circledR}$ is the official journal of the American Academy of Neurology. Published continuously since 1951, it is now a weekly with 48 issues per year. Copyright . All rights reserved. Print ISSN: 0028-3878. Online ISSN: 1526-632X.

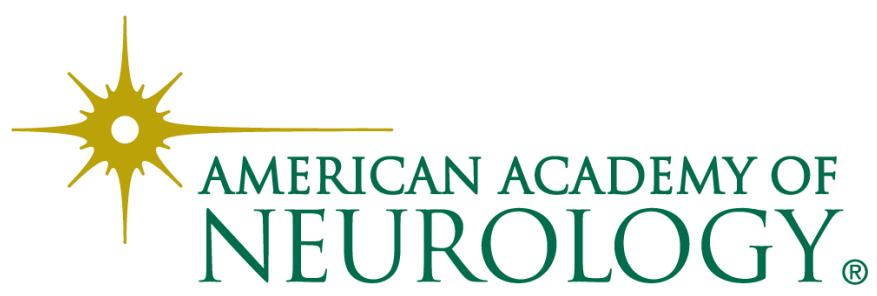

